症例

重症ダンピング症候群に対する逆蠕動空腸間置術の 5 例

\begin{tabular}{lcccccccccc}
\multicolumn{8}{c}{ 長崎大学第 1 外科（主任：富田正雄教授） } \\
三 浦 & 敏 & 夫 & 草 & 野 & 裕 & 幸 & 中 & 尾 & 治 & 彦 \\
川 & 口 & 昭 & 男 & 清 & 水 & 輝 & 久 & 福 & 田 & 豊 \\
中 & 越 & 享 & 平 & 野 & 達 & 雄 & 下 & 山孝 & 俊
\end{tabular}

足立晃太田勇司

重症ダンピング症候群 5 例に対して症状改善を目的として再手術を行った。症例は男 性 2 例，女性 3 例で，胃切除時年龄は25 50歳，原疾患は胃謴瘍 4 例之胃癌 1 例である. 初回術式は幽門側胃切除 4 例, 幽門側亚全摘 1 例で, 胃潰瘍の 4 例は Polya 型吻合, 胃 癌の 1 例は Billroth I 型吻合で再建されていた。 ダンピング症状は 1 例を除き胃切除術 後 3 週 1 カ月で発症し, 就労障害と栄養障害に上る体重減少をみた。病悩期間は $3 \sim 27$ 年で, 術前のX 線造影, 胃シンチグラムではいずれる胃内容の著明な排出促進がみられ た。再手術は残胃十二指腸間に $5 \sim 9 \mathrm{~cm}$ の空腸を逆蠕動性に間置し, 残胃に対して迷走 神経切離術を付加した。1 例は再手術を要したが，いずれる症状の改善を認め, 画像診 断でも胃内容排出時間の短縮をみた。

索引用語：早期ダンピング症候群，巡蠕動空腸間置術

はじめに

ダンピング症候群は胃切除後の合併症のうちでも食 事摄取と密接に関連をるって発現するすのであるが, 成因, 発現などの違いにより早期ダンピング症候群と 晚期ダンピング症候群に分けられている。

早期ダンピング症候群は胃切除術, 幽門形成術, 胃 腸吻合術後で, 食後30分以内に発現し, 発汗, 頻脈, 熱感, 顔面紅潮などの全身症状と腹鳴, 下乘, 腹痛, 腹部膨満などの消化器症状を現し，45分程度の持続を 示す。発現率は術式によって多少の差はあるが，0

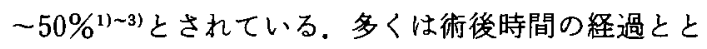
むに軽減し, 食事療法と薬物療法でコントロール可能 であり，手術の対象となるものは少なく $1 \%$ に満たな い上されている.

教室の過去15年間の消化性潰瘍症例の術後愁訴のう ち早期ダンピング症候群の頻度を術式別にみると, 選 択的近位迷走神経切離術で $12.5 \%$, 選択的迷走神経切 離術兼幽門洞切除術で18.7\%, 胃切除術では19.1\%で あり，これらのいずれる軽症で薬物投与を要するもの

1988年 7 月 16 日受付 1988 年12月 1 日採用
はなかった。

しかし最近相次いで重症ダンピング症候群の 3 例に 遭遇し，逆蠕動空腸間置術により症状の改善をみたの で, 長崎大学第 1 外科ならびに関連病院で経験した症 例を合わせ，5例について（表 1) 治療経過を゙述へ， 早期ダンピング症候群に対する術式ならびに本術式適 応上の問題点について文献的考察を加えて報告する。

\section{症 例}

症例 $1: 36$ 歳, 女性

主訴：食後の呕気, 発汗, 動悸.

家族歴：父44歳で肝硬変, 糖尿病で死亡.

既往歴：昭和 39 年 9 月交通事故で腹部を打撲し, 胃 半切除術 Billroth II (以下 B-II とする) 法吻合で再建 されている.

現病歴：昭和50年 1 月末より心窩部の重厌感，そう 䨃，続いて下痢が発現持続していた。同年 6 月，食後 30４0分して呕気, 発汗, 動悸, 呼吸困難が発現し,

下乘が持続するようになり $5 \mathrm{~kg}$ の体重減少をきたし た，長崎大学第 2 内科を受診し，入院精查の結果ダン ピング症候群と診断され，昭和51年 1 月 24 日に再手術 の目的で転科した。 
表 1 タンン゚ング症候群の 5 手術例

\begin{tabular}{|c|c|c|c|c|c|}
\hline & 症例 1 & 症例 2 & 盾例 3 & 症例 & 应例 \\
\hline 年齢・性 & $36 \cdot$ 女 & $52 \cdot$ 女 & 62 -男 & 53 • 男 & $5 \tau \cdot$ 女 \\
\hline 初回手術日 & 昭39. 9 & 昭33 & 昭37. 12 & 昭 50.3 & 昭53. 8 \\
\hline 初回矣患名 & 胃溃霧 & 胃馈痹 & 胃溃䅥 & 胃罢密・胆石 & 胃 癌 \\
\hline 胃切除術式 & B - II 胃切除 & B - I 胃切除 & B - II 胃切除 & B - II 胃切除 & B - I 胃切除 \\
\hline タンヒンク症状 & $\begin{array}{l}\text { 下焉・合开 } \\
\text { 嘔気・動言 }\end{array}$ & $\begin{array}{l}\text { 合汗・腹痛 } \\
\text { 下痢・主: } \\
\text { 充進 }\end{array}$ & 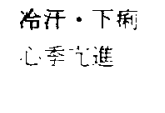 & $\begin{array}{l}\text { 下屟·腹痛 } \\
\text { 嘔気 }\end{array}$ & $\begin{array}{l}\text { 命开・湢気 } \\
\text { 嘔吐 }\end{array}$ \\
\hline 胃内容排出時間 & 万分ご Ba 排出 & 6 分 & 新 3 分 & 105 分 Ba 回盲 & 1 分 \\
\hline 再手術迄の期間 & 11年 万月 & 27年 & 24 年 6 月 & 1 年8月 & 8 年10月 \\
\hline 手術術式 & 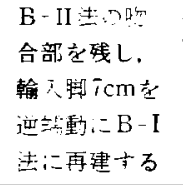 & 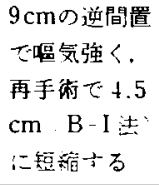 & 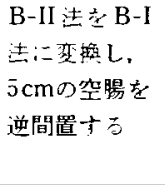 & $\begin{array}{l}7 \mathrm{~cm} \text { の空腸を } \\
\text { 道蝡動に B-I } \\
\text { 运で間置する }\end{array}$ & 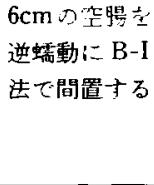 \\
\hline 传涹排出時間 & & 285 & $15 \%$ & & 万分 \\
\hline 成䝿：满足寞 & 良好 & 良好 & 良好 & 良好 & 崡めて良好 \\
\hline
\end{tabular}

現症：身長 $157 \mathrm{~cm}$, 体重 $42.5 \mathrm{~kg}$. 眹結膜に軽度の賓 血あり。心，肺に異常所見を認めない。腹部は平坦軟

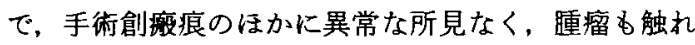
ない。

検查成績：一般検血，生化学検査は表 2 に示すごと く正常である.

空腹時血糖値は67 -97mg/dl で, 50g OGTT では糖 負荷後 30 分で $170 \mathrm{mg} / \mathrm{dl}, 60$ 分で $171 \mathrm{mg} / \mathrm{dl}$ となるが， $120 ， 180$ 分でそれぞれ66，57mg/dl と低下する。食事 摄取と呕気，血桾值之の関連性をみると，食後30分で 血糖は178 230mg/dl まで上昇， $2 \sim 3$ 時間後には 63～70mg/dl に低下する，呕気は低血糖時にその程度 が強くなっている，心電図は正常で，食後にはsinus tachycardia となる。. ${ }^{131}$ Iートリオレイン試験は血中吸取 率は $6 \%$ ，翼便中排泄率は1.1\%で正常である. 自律神 経試験ではアドレナリン試験(H)，ピロカルピン試験 (\#)，アトロピン試験 (一) で, 全自律神経緊張え進 と判定した.

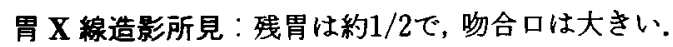
充満像, 二重造影像で異常所見は認めない。バリウム 排出を継時的にみたが, $50 \mathrm{ml}$ を飲をせた直後速やかに 空腸へ通過し，5分後に呕気が現れるが，すでにバリ ウムは胃内にほとんど残存せず，心窝部の不快感を訴 えた.

胃内視鏡検查では吻合口が大きく，軽度の発赤を呈
する他に異常所見は認めなかった。

以上の結果, 自律神経失調の関与はあるすのの, 食与 事摄取あるいはバリウム投与に関連した消化器・循環 器症状の発現を見ることよりダンピング应候群と診 断し手術を行った。

手術術式：昭和 51 年 2 月 5 日, 全身麻醉下に開腹し た. B-II 法吻合で再建され，胃の約半分が残されてい た. 吻合口を温存し，輸出脚を残胃に接して切離閉鎖 した。翰入脚は $7 \mathrm{~cm}$ 離して切離し，前回手術で閉鎖し た十二指腸断端を露出, 端々吻合で再建し, 翰入脚口 側端と輸出脚肛側断端を端々吻合した。従って Billroth I (以下 B-I とする) 法形式で約 $7 \mathrm{~cm}$ の逆蠕動空 腸を間置したことになった。残胃には幹迷走神経切離 術を付加した（図 1A）。な扰十二指腸は長期間空置さ れていたため，管腔は狭小化し，粘膜は萎縮を示して いた。

術後経過：術後は心窝部膨満感と呕気が持続した が、ダンビンダ症状は軽減した。術後 4 週間後のバリ ウム造影では逆蠕動は観察されるが排出障害はなく， 7 分後には回腸に達し，胃内残存は $1 / 4,60$ 分後には胃 内にバリゥムは認めなかった。3月19日症状持続のま ま退院した。 その後 1 - 2 年間は食事の停滞感が残存 したが，次第に軽块し術後約12年の現在ほとんと症状 はなく体重す一定し家事に従事している。

症例 $2: 52$ 歳, 女性 
表 2 入院時検查成績

\begin{tabular}{|c|c|c|c|c|c|}
\hline 検查項目 & 症例 1 & 症例 2 & 症例 3 & 症例 4 & 症例 5 \\
\hline $\mathrm{RBC}\left(/ \mathrm{mm}^{3}\right)$ & $411 \times 10^{4}$ & $429 \times 10^{4}$ & $472 \times 10^{4}$ & $438 \times 10^{4}$ & $354 \times 10^{4}$ \\
\hline $\mathrm{WBC}\left(/ \mathrm{mm}^{3}\right)$ & 4800 & 2100 & 6600 & 5300 & 3400 \\
\hline $\mathrm{Hb}(\mathrm{g} / \mathrm{dl})$ & 11.5 & 11.9 & 14.3 & 13.6 & 8.2 \\
\hline Ht $(\%)$ & 36.0 & 35.9 & 43.7 & 41.7 & 39.5 \\
\hline Plt $\left(/ \mathrm{mm}^{3}\right)$ & $19.0 \times 10^{4}$ & $21.6 \times 10^{4}$ & $15.1 \times 10^{4}$ & $17.5 \times 10^{4}$ & $38.8 \times 10^{4}$ \\
\hline 出血時間（分） & 3.5 & 3 & 2 & 1.5 & 3 \\
\hline 凝固時間（分） & $5-16$ & $4-10$ & $8-16$ & $2.5-6$ & $5-11$ \\
\hline T.P. $(\mathrm{g} / \mathrm{dl})$ & 7.4 & 6.4 & 6.7 & 7.7 & 7.6 \\
\hline Alb. $(\mathrm{g} / \mathrm{dl})$ & 4.6 & 4.3 & 4.6 & 3.8 & 4.7 \\
\hline T.Bil. (mg/dl) & 0.5 & 0.7 & 0.5 & 0.46 & 0.5 \\
\hline D.Bil. (mg/dl) & 0.2 & 0.3 & 0.2 & 0.2 & 0.2 \\
\hline GOT (IU/L) & 21 & 22 & 34 & 17 & 19 \\
\hline GPT (IU/L) & 11 & 16 & 29 & 6 & 10 \\
\hline$\gamma$-GPT $(\mathrm{IU} / \mathrm{L})$ & 12 & 16 & 82 & 15 & 12 \\
\hline $\mathrm{TTT}(\mathrm{U})$ & 8.9 & 0.8 & 1.0 & 1.7 & 2.3 \\
\hline ZST (U) & 6.7 & 5.3 & 4.1 & 7.0 & 10.1 \\
\hline $\mathrm{Al}$-pase & $5.2 \mathrm{KAU}$ & $182 \mathrm{IU} / \mathrm{L}$ & $181 \mathrm{IU} / \mathrm{L}$ & $162 \mathrm{IU} / \mathrm{L}$ & $7.6 \mathrm{KAU}$ \\
\hline $\mathrm{ChE}(\mathrm{U} / \mathrm{L})$ & 1.08 & 0.66 & 0.94 & 0.82 & 0.76 \\
\hline フミラーセ (S.U) & 255 & 180 & 216 & 142 & 295 \\
\hline LAP (IU/L) & 59 & 71 & 74 & 66 & 99 \\
\hline $\mathrm{LDH}(\mathrm{IU} / \mathrm{L})$ & 257 & 206 & 211 & 196 & 223 \\
\hline $\mathrm{K}(\mathrm{mEq} / \mathrm{L})$ & 4.6 & 3.9 & 4.0 & 3.5 & 4.3 \\
\hline $\mathrm{Na}(\mathrm{mEq} / \mathrm{L})$ & 142 & 145 & 148 & 144 & 142 \\
\hline $\mathrm{Cl}(\mathrm{mEq} / \mathrm{L})$ & 107 & 106 & 108 & 100.9 & 105 \\
\hline$P(\mathrm{mEq} / \mathrm{L})$ & 3.0 & 3.5 & 3.3 & 3.4 & 3.5 \\
\hline $\mathrm{Ca}(\mathrm{mEq} / \mathrm{L})$ & 9.0 & 9.0 & 9.3 & 4.3 & 6.5 \\
\hline 血清鉄 $(\mu \mathrm{g} / \mathrm{dl})$ & & 161 & 161 & & \\
\hline 血清ブラディキニン $(\mathrm{pg} / \mathrm{ml})$ & & & $5>$ & & \\
\hline 七ロトニン $(\mathrm{ng} / \mathrm{ml})$ & & & 207 & & \\
\hline ヒスタミン (ng/ml) & & & 26 & & \\
\hline ガストリン $(\mathrm{pg} / \mathrm{ml})$ & & & 48 & & \\
\hline セクレチン $(\mathrm{pg} / \mathrm{ml})$ & & & $50>$ & & \\
\hline $\mathrm{BUN}$ (mg/dl) & 15 & 12 & 22 & 19.4 & 15.4 \\
\hline クレアチニン $(\mathrm{mg} / \mathrm{dl})$ & 0 & 0.90 & 1.0 & 0.80 & 0.8 \\
\hline 検尿 糖 & $(-)$ & $(-)$ & $(-)$ & $(-)$ & $(-)$ \\
\hline 蛋白 & $(-)$ & $(-)$ & $(-)$ & $(-)$ & $(-)$ \\
\hline ウロビリノーゲン & 正 & 正 & 正 & 正 & 正 \\
\hline PSP（60分） & $80.0 \%$ & $78.7 \%$ & $74.3 \%$ & $75.0 \%$ & $85.0 \%$ \\
\hline
\end{tabular}

主訴：食後の心悸穴進, 冷汗, 腹痛之下㓫。

既往歴：18歳で虫垂切除術を受け，瘻孔形成のため 回横行結腸吻合術がなされ，25歳で胃潰湯の診断で胃 切除術が行われている。

現病歴：胃切除術の後数力月後上り, 食後 10 分位で 動悸, 冷汗, めまいが現れ, 同時に腹鳴, 腹痛, 呕気,

下痢などを伴らよらになった，横臥すると症状は軽减 するが仕事に就くことは不可能で年前中はほとんど休 養していた，対症療法がなされてきたが症状の改善が 得られず，体重减少が著しく，早期ダンピング症候群
として外科的処置を期待し当科に紹介され，昭和 60 年 10月 3 日入院した。

検查成績：一般検血，生化学検查はほぼ正常である が(表 2)，75g OGTT で糖負荷 7 分後にダンピング症 候群が発現し, 30 分後に $250 \mathrm{mg} / \mathrm{dl}$ まで上昇, 60 分後に 血糖値は $77 \mathrm{mg} / \mathrm{dl}$ と下降し, hyperoxyglycemia した.

米飯パリウムによるX 線造影では排出速度が早く， 投与造影剤の胃よりの阷落, 摘出感を訴克, 数分後に 動悸，冷汗，腹痛，呕気を訴えた。胃シンチグラムに 


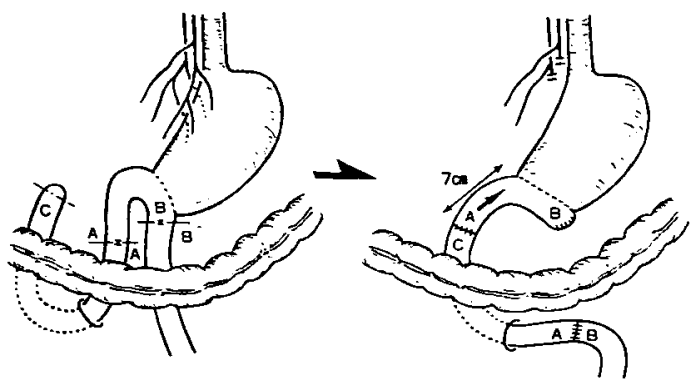

A
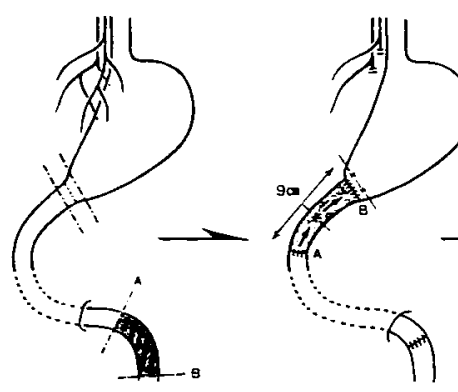

B

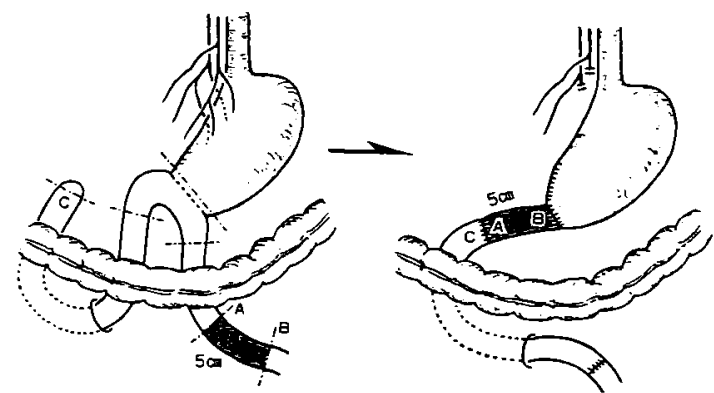

C

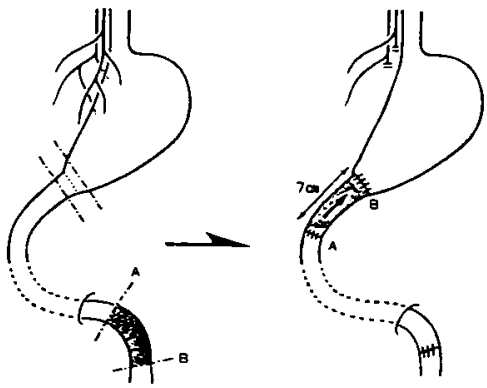

D

図 1 逆蠕動空腸間置術（迷走神経切㜠術付加）のシェーマ

A. 症例 1 ：吻合部と翰入脚を利用した逆蠕動間置 (B-II 法 $\rightarrow$ B-I 法)。 B. 症例 2 ： 間置空腸を再手術により短縮, (1) 術前 (2) $9 \mathrm{~cm}$ 空腸逆間置 (3) $4.5 \mathrm{~cm}$ に短䑿. C. 症例 3 : 吻合部を切除し, $5 \mathrm{~cm}$ を逆蠕動間置 (B-II 法 $\rightarrow$ B-I 法). D. $7 \mathrm{~cm}$ 空腸逆 蠕動間置

よる胃内容排出曲線は急峻に下降し、T1/2は約 7 分で 短かった（図 2-1）.

手術棞 1 に示すごとく，B-I 型吻合がなされた残 胃に選択的迷走神経切離術を行ない, $9 \mathrm{~cm}$ の空腸を有 茥とし，結腸後に挙上し胃十二指腸間に逆蠕動性に間 置した（图 1B-2）。術後は合併症なく順調に経過し， 娣食摄取時も発汗などダンピング应状は見られなかっ たが，摄食量を増加するに従い腹满と呕気を訴え，著 しい排出障害が出現した。 X 線造影でも間置腸管の活 発な逆蠕動運動がみられ，排出は緩徐で胃は抎張し， シンチグラムの $\mathrm{T} 1 / 2$ も測定不能で術前に比し著明に 延長した（図 2-2）。症状の改善をみないため3カ月後 再手術を行い，間置空腸を切除し $4.5 \mathrm{~cm}$ とした(図 $1 B$ -3).

再手術術後は早期ダンピング症状と胃排出障害は消 失し，時に停滞感を訴えるに止まっている，ガストロ シンチでは T1/2は27分で(図 2-3)，正常者に近い排出 状態となっている。術後 2 年の現在健在で職場に復㷌 している.
症例 $3 ： 62$ 歳, 男性 (870293)

主訴：食後の冷汗，全身僚总感。

家族歴：父に糖尿病あり，㜆溢血で死亡，妹が関節 リウマチ.

既往歴：昭和37年12月胃潰瘍で胃切除術を受け，昭 和61年12月経尿道的前立腺切除術を受けている.

現病歴：胃切除術後 6 力月程経過して上り, 食直後 に冷汗，心情方進などが出現し，腹痛はないが，下峲 を伴らことが多く，横臥を余儀なくされていた，1時 間位眠ってしまらと軽快する。これら症状は米飯摄取 で症状が強く，麵類では起こりにくい，体重は約 $10 \mathrm{~kg}$ 减少した。再手術により症状の改善を期待して昭和 62 年 4 月13日入院した。

現症：身長 $160.0 \mathrm{~cm}$, 体重 $45.0 \mathrm{~kg}$ で度身である.脈 拍 $60 /$ 分整. 䀫結膜に貟血なく，心肺に異常所見を認め ない，腹部平坦軟で，圧痛なく，異常な腫瘤も触れな w.

検査成樍：一般挨血，生化学検査は表 2 に示すごと く正常である. 


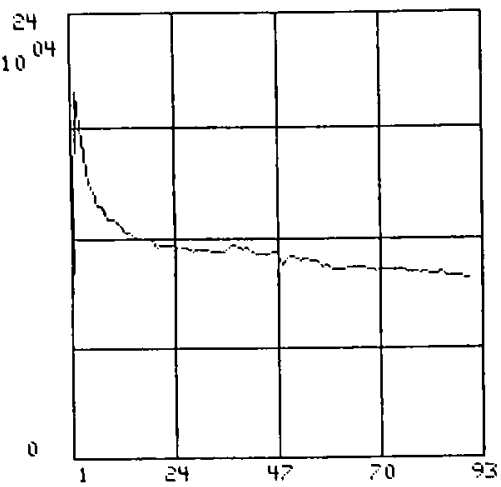

1. 術前

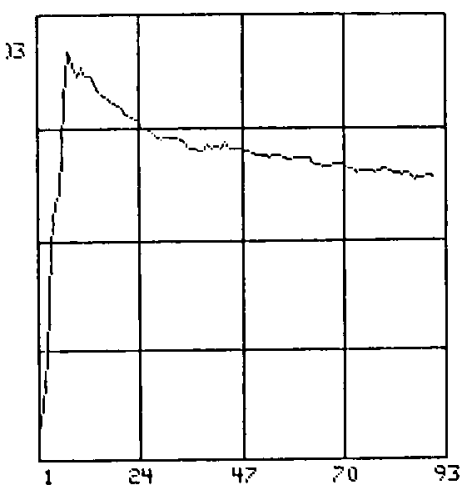

2. 術後

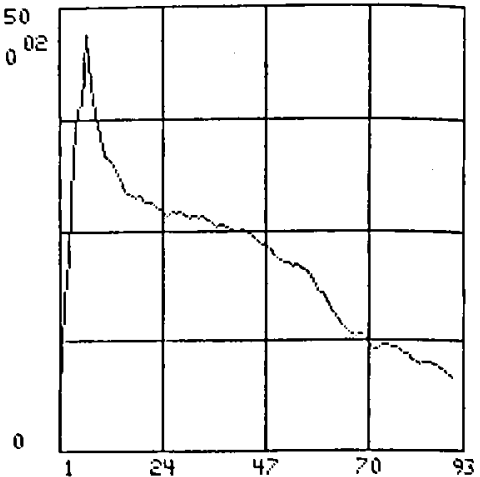

3. 再手術後

図 2 胃シンチグラム（症例 2)

空腹時血糖值は $58 \mathrm{mg} / \mathrm{dl}, 75 \mathrm{~g}$ OGTT で，30分後に $210 \mathrm{mg} / \mathrm{dl}$ まで上昇するが，呕気，むたれ感を訴え，60， 120 分後に血糖值は $127,40 \mathrm{mg} / \mathrm{dl}$ と下降し, hyperoxyglycemia を呈したが，低血糖発作を見るには至らな かった。

胃 $\mathbf{X}$ 線造影所見：B-II 吻合がなされている, 造影剤 は輸入脚に逆流するが，残胃おょび吻合部に潰湯性病 变は認めない.

シネガストログラフィー：米飯バリウムによるX 線像は排出速度が早く, 投与造影剤の胃上りの邽落感 を訴光，日頃食後に発現している呕気を訴えた，10分 後の遺残バリウムは胃壁に付着する程度であった。

胃内視鏡検查所見：吻合口の輸出脚に白苔を被った 類円形の治痹期の小潰演を認めた.

胃シンチグラム：胃内容排出曲線は急峻に下降し, $\mathrm{T} 1 / 2$ は約 3 分で極めて短く, 胃内容の排出は速かった (図 3).

胆道シンチグラム：胆汁の小腸への排出は円滑で, 胃内への逆流は認めなかった。

自律神経試験：アドレナリン試験：心悸六進軽度認 めるのみで, 総合判定は (十)で, 軽度の交感神経系 の緊張え進状態を示した。

メコリール試験：筋注直後に一過性の熱感を訴える が，脈拍は安定. 中間型であった。 以上の所見よりダ ンピング症候群と診断し，手術の適応とした。

手術所見：昭和62年 5 月 6 日手術を施行した。全身 麻酔下に上腹部正中切開で開腹した。残胃は $1 / 3$ 以上残 されて括り，B-II 法 (Polya 型) で結腸後に吻合され ており，吻合口径は大きかった。輸出脚はやや膨満し ているが, 術前内視鏡で認めた吻合部潰瘍の存在を思

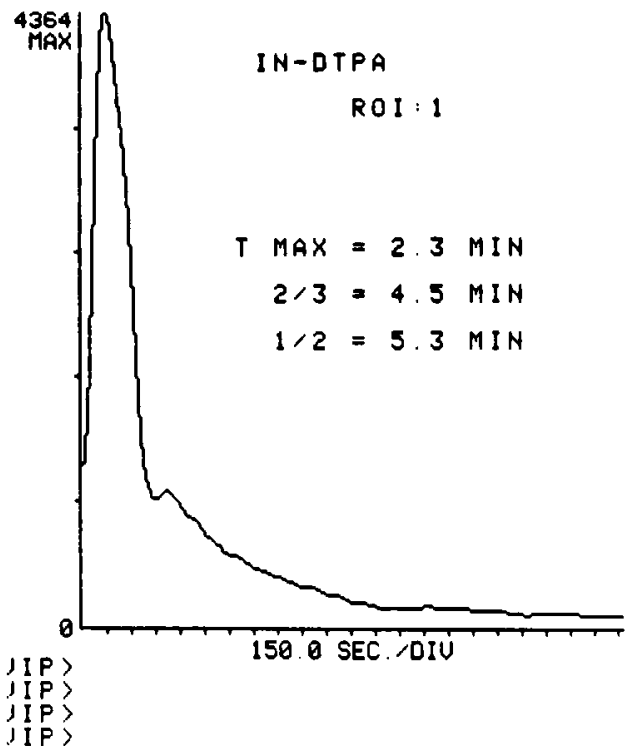

図 3 胃シンチグラム（症例 3）

わせる将膜の変化はなかった。十二指腸の閉鎖断端部 は長期間の空置で不用性萎縮をきたし細い，選択的迷 走神経切離術を付加し, 吻合部に接して自動縫合器 PLS 90を装着, 肛門側を切離，ついで輸入脚を吻合口 より $5 \mathrm{~cm}$, 輸出脚を $10 \mathrm{~cm}$ 離してそれぞれペッッで切離 し, 吻合部切除を完了する. 輸出入脚を端々吻合し, トライッ勒帯より $25 \mathrm{~cm}$ の部より $5 \mathrm{~cm}$ 長の空腸を有䔤 とし遊離し, 結腸後に挙上, 逆蠕動性に置き, 胃断端 大弯と有茥空腸を ILS 29で二重器械法で吻合した。 空 腸口側と十二指腸の吻合は二層で端々吻合し逆蠕動空 腸間置術を完了したが，十二指腸壁が薄く粘膜は萎縮 
をきたしていた（図 1C）。

術後経過：食後の発汗，呕気などダンピング症状は 消失し, 軽度の胃停带感を訴えるが, 術後 7 カ月の現 在ほぼ満足した結果を得ている。

症例 $4: 53$ 歳, 男性.

主訴：食後の下为, 冷汗.

家族歴：特記すべきことなし。

既往歴：昭和 48 年 2 月頃より空腹時心窝部痛を認 わ, 胃潰瘍と胆石の診断を受け，50年 3 月 24 日某病院 で胃切除術 B-I 型吻合と胆震摘除術がなされている.

現病歴: 術後 $1 \sim 2$ 力月経過して上り, 食後20３0 分後に腹鳴, 下麻, 冷汗が発現した。食事・薬物療法 によるも改善の改候なく, 下浰の回数が $3 \sim 4$ 行とな り，腹痛を伴い体重減少をきたしたため再手術を希望 し入院した.

現症：身長 $165.0 \mathrm{~cm}$, 体重 $51 \mathrm{~kg}$. 心, 肺に異常所見 を認めない，腹部は平坦で，異常な腫瘤を触れない。

検査成績：一般検血，生化学検查では異常を認めな 小(表 2 ).

手術所見：昭和51年11月 5 日手術, B-I 吻合の吻合 部を切除し, $7 \mathrm{~cm}$ の空腸を逆蠕動に挙上し, 残胃十二 指腸間に間置した（図 1D）.

術後経過：術後 2 - 3 年間は多少の胃もたれ感が牫 存したが，下蜊は消失し，体重も增加し，11年経過後 の現在健在である。

症例 $5: 57$ 歳, 女性.

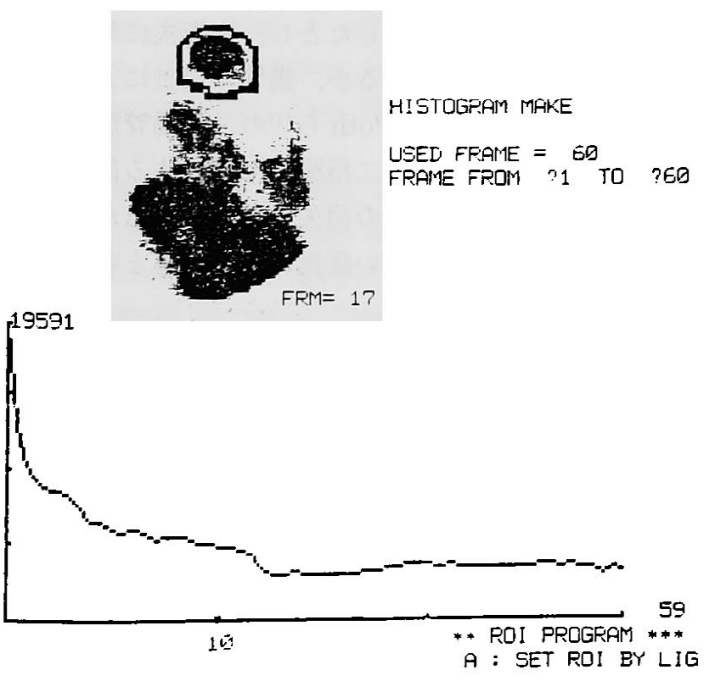

1. 術前
主訴：食後の冷汗, 呕気, 腹鳴.

家族歴：特記することなし。

既往歴：昭和53年 8 月 4 日胃癌のため田川市立病院 に入院. 胃亚全摘術・摘脾術がなされ, Billroth I 吻合 で再建された。

現病歴：胃切除術後 3 週間目頃より食後 $5 \sim 10$ 分し て腹鳴, 腹痛, 下虫が発現し, 顔面紅潮·熱感を伴い, 全身倦意感, めまいが強く, 食後 2 時間程度は臥床を 必要とした。症状は摄取食事が流動性のるので著しく, 食事内容を低含水炭素とし, 水分を制限し, 種々の薬 物療法を行ったが軽快せず, 体重減少と仕事（教員生 活）に支障をきたした。昭和56年退職したが，負血と 低栄養状態のため年に 1 - 2 回入院し, 輸夜や輸血を 行っていた。再手術で症状の改善を期待して入院した。

現症：身長 $162 \mathrm{~cm}$, 体重 $42 \mathrm{~kg}$ で演身である. 胸, 腹 部に理学的に異常所見は㑊めない.

検查成績：一般検血，生化学検查結果を表 2 亿示す が，負血と低蛋白血症がみられた。

空腹時血糖値は77mg/dl, 50g OGTT で30分後に183 $\mathrm{mg} / \mathrm{dl}$ まで上昇するが，呕気，もたれ感を訴点，60分 後に $250 \mathrm{mg} / \mathrm{dl}$ で最高値に達し，12分後には $134 \mathrm{mg} / \mathrm{dl}$ と低下した。

胃 $\mathbf{X}$ 線造影：バリウム米飯による胃透視では通過 が速く，3分後にはほとんど非出した。

胃シンチグラム ${ }^{99 m} \mathrm{~T}$ c に上る半減期は約 1 分で早期 に消失した（図 4-1）。

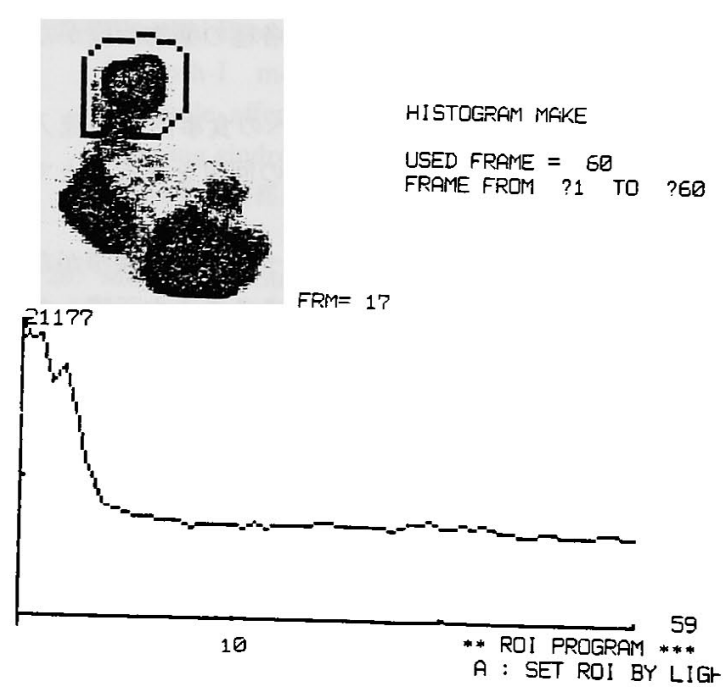

2. 術後

図 4 胃シンチクラム（症例 5 ) 
手術所見：昭和62年 6 月 24 日全身麻醉のもとに開腹 した。胃癌の再発を思わせる所見はなく，トライッ靯 帯より $15 \mathrm{~cm}$ 肛側より $6 \mathrm{~cm}$ の空腸を遊離し, 残胃十二 指腸間に逆蠕動性に間置した。

術後経過：術後は順調に経過し, 経口摄取開始後は 術前見られたダンピング症状は完全に消失し，軽度の つか感を残すのみで，流動性の食事も高炭水化物の 摄取も可能となり，体重も漸次増加を示している.

胃シンチグラムによる排出曲線るなだらかとなり， $\mathrm{T} 1 / 2$ は 4 分と術前に比較して延長を示した（図 4-2）. $50 \mathrm{~g}$ GTT では術前の DM 型は正常型に変化した。

\section{考 察}

ダンピング症候群の診断基準には他覚的なるのはな く，報告者によって異なり，発生率に打いて子差があ る. 本邦では日本消化器外科学会》炕おいて全身症状 11項目と腹部症状 7 項目が挙げられており, 食啳30分 以内に全身症状の内 1 つ以上と腹部症状を有するもの を診断基準としているが，教室でるこの基準によって 問診ならびにアンケート調査を行い発生率を算出して いる. 今回報告の 5 例はいずれるこの基準を満足し, 加えて就労障害をるち，体重減少中栄盖障害を有すむ ので重症とした。

治療法はまず一般的な食事指導と薬物療法が行われ るが，手術の適応として Fenger ${ }^{5}$ は 1 年以上ダンピン

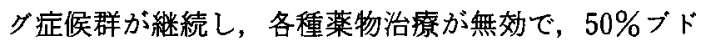
ウ糖液 $250 \mathrm{ml}$ の空腸内への緩徐な注入でダンピング症 候が発現するものを举げている，わ的わ症例はい、 ずれす年余にわたり，食事療法と各種の薬物治療がな され無効であった者である。

手術療法の原則は 1 . 上部小腸への食事内容の流入 を緩徐にすること，2. 胃の貯溜襄の回復を計ることで ある.

Hert $z^{6)}$ は胃腸吻合口径の縮少, 十二指腸の狭窄がな ければ胃空腸吻合の除去が有効であることを示唆した が, Grassi は吻合口を $1.9 \mathrm{~cm}$ 以下とし, Mix ${ }^{7}$ は胃空腸 吻合を除去し排出の遅延に成功した. Jenkins ${ }^{8}$, Christiansen ら9"㥜腸吻合を幽門成形に変換して 60〜100\%の成功率を収めている，胃腸吻合のB-II 法 より I 法への変換では, Sewak ${ }^{10}$ は30例で71\%の成功 を挙げ、Woodward ${ }^{111}$ は11例で72.7\%に有効であった としている，乙かしもっとも有効で合理的な術式は空 腸間置術で，1）順蠕動空腸間置術，2）逆蠕動空腸間 置術，3）二重腸重形成間置の 3 つの方法がある. 順蠕 動間置莄では20〜 $25 \mathrm{~cm}$ の空腸が用いられるが,
Mendoza ${ }^{12)}$, Bushkin ら ${ }^{13)}$ は総て良好な結果を得たと し, Nygaad ら 14/は59\%はきわわて良好, 36\%には改善 がみられたとしているが，Fenger ${ }^{15)}$ は30例の32力月に 及ぶ追跡で $20 \%$ の緩快をみたに過ぎなかったと述べて いる. 一般的に非常に有効な方法であるが，吻合部嘳 瘍の発生が30\%に達すると言われているので迷走神経 切離術の付加が必須である.

逆蠕動間置術としては Hammer ${ }^{16)}$, Willms $5^{17118)}$ の実験的, 臨床的結果に基づき，6〜10cm の空腸が用 いられている. Herrington ら”の比較試験によると, 術後満足率は順蠕動法の $20 \%$ ，二重腸管形成法の $60 \%$

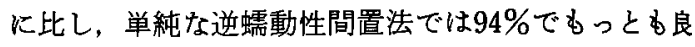
好である。これら成績に基つきわれわれす 5 例に対し 5〜9cm を間置し 4 例は良好に経過した。しかし $9 \mathrm{~cm}$ を用いた症例 2 では術後強度の停滞感が出現し, 再手 術により間置腸管の切除を余儀なくされた。従って逆 蠕動空腸間置に当って最も留意すべきことは空腸の長 さである，透視下の観察でみても長い間置腸管の逆蠕 動運動は予想以上に強く，迷切に上る胃壁の緊張低下， わ加わり排出障害が必発であり， $10 \mathrm{~cm}$ 以上の間置は 採るべきではないと考えている。輸入脚を利用した B-II法よりI法への变換により逆蠕動間置は Benedini ら ${ }^{19}$ が試みたものであり，吻合口部の空腸を 遺残することにより残胃容量の増大を企图するすの で,われわれる症例 1 で本術式を採用し良好な結果を 得た。一方 Roux-Y吻合に上る逆蠕動間置は Woodward ら ${ }^{20}$ が $10 \mathrm{~cm}$ の空腸を用い試みたが，5例 中 3 例に再手術を必要としたとし，本術式に対しては 否定的な見解を述べているが，腸管の過長によるもの であろらと考えられる.Poth ら ${ }^{21}$ の重腸管法は形成 空腸を順逆蠕動性に胃十二指腸間に間置する術式であ り，8例に行い全例症状の消失を認めているが，術式 が複雑であり残胃の小さい症例にのみ適応と考えてい る.

最後に本症の発生には神経症的素因む関与してお り，再手術術後においても患者に対する生活指導が必 要である．また胃癌に打ける胃切除後においても低率 ではあるが症例 5 のように本症の発生をみることよ り，残胃の極小な治㾤的胃覀全摘術に対しては予防的 空腸間置術 ${ }^{22)}$ 考慮すべきであろらと考える。

$$
\text { まとめ }
$$

長崎大学第 1 外科ならびに関連病院で就労不能で栄 盖障害をもつ重症早期ダンピング症候群の 5 例に対し て, 症状改善を目的として再手術を行った，対象は初 
回手術時25 50歳の男性 2 例と女性 3 例で病脳期間は 3ー27年であった。再手術術式は B-I 法による逆蠕動 空腸間置術がなされたが，4例は症状の改善とともに 画像診断による胃内容排出時間の短縮が認められた が，間置腸管の過長であった 1 例は，術後排出障害が 現れ, 再手術により間置腸管を短縮し症状の楥解を得 た.

\section{文 献}

1) Herrington JL Jr, Sawyers JL: Remedial operations. Edited by Nyhus LM, Wastell C: Surgery of the Stomach and Duodenum. 3rd ed. Little Brown, Boston, 1977, p537-566

2) Goligher JC, Feather DB, Hall R, et al: Several standard elective operations for duodenal ulcer : Ten to 16 year clinical results. Ann Surg $189: 18-24,1979$

3) Andrews EW : "Dumping stomach" and other results of gastrojejunostomy : Operative cure by disconnecting old stoma. Surg Clin Chic $4: 879$ $-892,1920$

4）山口吉康: 共同調査成績よりみた自覚症状パター ンならびに調査項目およびダンピング症候群判定 基準の検討, 日消外会誌 $4: 3-4,1972$

5) Fenger $\mathrm{HJ}$ : The dumping syndrome and gastric emptying with a discussin on the medical and surgical treatment. Acta Chir Scand 129 : $86-95,1965$

6) Hertz AF: The cause and treatment of certain unfavorable aftereffects of gastroenterostomy. Ann Surg 58 : 466-472, 1913

7) Mix CL: "Dumping stomach" following gastrojejunostomy. Surg Clin North Amer 2: 617 $-622,1922$

8) Jenkins DJA, Gassull MA, Leeds AR, et al : Effect of dietary fiber on complications of gastric surgery : Prevention of postprandial hypoglycemia by pectin. Gastroenterology 73: 215 $-217,1977$

9) Christiansen PM, Hansen $O H$, Pedersen $T$ : Reconstruction of the pylorus for postvagotomy diarrhoea and dumping. $\mathrm{Br} \mathrm{J}$ Surg $61: 519-520,1974$

10) Sewak JH, Movius HJ : Restoration of gastroduodenal continuity. JAMA 171 : 1804-1806, 1959

11) Woodward ER, Hastings $N$ : Surgical treatment of the postgastrectomy dumping syn- drome. Surg Gynecol Obstet $111: 429-437,1960$

12) Mendoza CB, Easley GW, Gerwig WH : Jejunal interposition as remedial operation for severe dumping syndrome. Am J Surg 125 : 318 $-323,1973$

13) Bushkin FL, Woodward ER, O'Leary JL: Experience with the jujunal loop interposition in the treatment of postgastrectomy disorders. Am Surg 43: 101-107, 1977

14) Nygaad K, Fretheim B : Jejunal transposition in treatment of postgastrectomy syndromes. Scand J Gastroenterol 9:59-64, 1974

15) Fenger $\mathrm{HJ}$, Gudmand-H $\phi$ yer $E$, Kallehauge $\mathrm{HE}$, et al: Clinical experience with isoperistaltic interposition of a jejunal segment for the incapacitating dumping syndrome. Ann Surg 175: 274-278, 1972

16) Hammer JM, Seay PH, Johnston RL, et al : The effect of antiperistaltic bowel segments on intestinal emptying time. Arch Surg 79:537 $-541,1959$

17) Willms RK, Barton HL, et al: Reversed intestinal segments and their effect upon gastro-intestinal motility, nutrition and the dumping syndrome following subtotal gastrectomy in dogs. Am Surg $29: 356-370,1963$

18) Willms RK, Jordan GL Jr : Reversed jejunal segment: Effect on gastric emptying and nutrition following subtotal gastrectomy in six dogs. JAMA 178: 1008-1011, 1961

19) Benedini E, et al : Conversione di Billroth-II in Billroth-I mediante trapiante dell-ansa digiunale afferente al duodeno in un caso di dumping sindrome precosa grave. Chir Itali 12 : 69,1960 (渡部洋三：胃切除後のダンピング症候 群, 外治 $56: 41-49,1987$ より引用)

20) Miranda R, Steffes B, O'Leary JP, et al : Surgical treatment of the postgastrectomy dumping syndrome. Am J Surg 139: 40-43, 1980

21) Poth EJ: Surgical correction of severe "dumping" and postgastrectomy malnutrition : A therapeutic and diagnostic test. Ann Surg 160:488 $-496,1964$

22）三浦敏夫，石井後世，下山孝俊他：胃覀全摘術に対 する二重腸管形成移植術，手術 $39:$ 1453-1459, 1985 


\title{
CLINICAL EXPERIENCE WITH ANTIPERISTALTIC INTERPOSITION OF A JEJUNAL SEGMENT FOR SEVERE DUMPING SYNDROME
}

\author{
Toshio MIURA, Hiroyuki KUSANO, Haruhiko NAKAO, Akio KAWAGUCHI, Teruhisa SHIMIZU, \\ Yutaka FUKUDA, Tohru NAKAGOE, Tatsuo HIRANO, Takatoshi SHIMOYAMA, \\ Akira ADACHI and Yuji OHTA \\ First Department of Surgery, Nagasaki University School of Medicine and Department of \\ Surgery, Tagawa Municipal Hospital
}

To obtain symptomatic remission, five patients with severe dumping syndrome have received reoperations. The patients, including two males and three females, had undergone gastrectomy when they were from 25 to 50 years old because of gastric ulcer (in 4 cases) or gastric cancer (in one).

The first surgical procedures were pylorous-side gastrectomy in 4 and pylorous-side subtotal gastrectomy in one case. Four cases of gastric ulcer or one of gastric cancer received Polya or Billroth I anastomosis respectively. Excepting one case, dumping syndrome occurred around postoperative 3 weeks to one month, and a difficuty to work and a weight-loss due to malnutrition were noted. They have been sufering from the syndrome for 3 to 27 years.

Preoperative X-ray examination and gastric scan revealed a significantly stimulated exhausion of the stomach in each case. In the reoperation, the jejunum, $5 \sim 9 \mathrm{~cm}$, was placed antiperistaltically between the residual stomach and duodenum, and vagotomy was added to the residual stomach. Though one case needed the third sugical treatment, symptomatic remisson was noted in all cases and scintigram revealed a shortening of exhausion time of the stomach. 